\title{
PROSPECTIVE CONSTITUTIONAL CHANGES IN KOSOVO EMANATING FROM THE EU PRE-ACCESSION PROCESS
}

\author{
Visar Morina*
}

\begin{abstract}
Summary: Although Kosovo is in the initial period of its European integration process, this article will analyse the extent to which the 2008 Kosovo Constitution is compatible with EU law. Integration in the European Union is one of the key objectives of Kosovo's constitutional preamble and the paper will discuss the prospective constitutional amendments that will occur in Kosovo in anticipation of accession to the European Union. The author's position is that a great part of constitutional non-compliance with EU law can be solved through constitutional interpretation (eg the partial transfer of sovereignty), while other issues will require parliamentary intervention through constitutional amendments, a process which does not always run without difficulty in Kosovo's democracy. In this paper, it is argued that the Kosovo Constitution will require a small package of constitutional amendments during the pre-accession process. Constitutional amendments will be required to ensure the precedence of EU law, but also to ensure that the right to vote and to stand as a candidate in municipal elections by citizens of the EU is guaranteed. Further, the article analyses the kind of impact the EU integration process will have on other specific constitutional issues in Kosovo, such as freedom of movement and the surrender of nationals to other Member States, and what constitutional choices there are to avoid any contradiction between the Constitution and EU law. The study takes into account constitutional adaptations in several Central and Southeast European countries on their path towards EU integration, which can serve as guidelines for the decisionmaking authorities in Kosovo to identify constitutional gaps and flaws in the course of the EU pre-accession process.
\end{abstract}

\section{Introduction}

Kosovo is at an early stage of its path towards European integration compared to other countries of the Western Balkans. ${ }^{1}$ Only in 2016 did Kosovo ratify the Stabilisation and Association Agreement (SAA), which is

\footnotetext{
Dr Visar Morina is Professor of Constitutional Law at the University of Prishtina in Kosovo, email visar.morina@uni-pr.edu. This study has been supported by funding from Friedrich Ebert Stiftung - Kosovo.

1 For an overview of the European Integration process on the Western Balkans, see Roberto Belloni, 'European Integration and the Western Balkans: Lessons, Prospects and Obstacles' (2009) Journal of Balkan and Near Eastern Studies 313.
} 
the first formal agreement between the European Union (EU) and Kosovo on enhancing political dialogue, closer trade integration, including opening EU markets to Kosovo's industrial and agricultural products. The ratification of the Stabilisation and Association Agreement with Kosovo was made with a 'status neutrality' approach given that several Member States had not yet recognised the independence of Kosovo, impeding obviously its EU integration prospects. As the 2015 EU progress report for Kosovo observed, among the key elements of Kosovo's process towards EU integration is the alignment of its legislation with the EU acquis. ${ }^{2}$ In a broader context, such legislative alignment with EU norms includes a Constitution that permits the EU accession process. As shown by the experience of the countries that have joined the EU, constitutional adaptation has been necessary before and after accession to ensure compliance with EU treaties. Such constitutional changes originating from the EU integration process have been wide-ranging and have led to what Rodin has termed a 'constitutional revolution'. ${ }^{3}$ One recent example of the impact of the EU integration process on the Kosovo Constitution is a recent constitutional amendment that changed the balance of the composition of the Kosovo Judicial Council (the KJC) in favour of the judiciary. Previously, the majority of the members of the KJC were elected by the Assembly of Kosovo (AoK), which prompted the European Commission to address critical remarks that this constitutional arrangement may lead to strong political interference and can jeopardise the independence of the judiciary by the political parties represented in the Assembly. ${ }^{4}$ In an effort to meet the EU integration requirements for the independence of the judiciary, the AoK adopted a constitutional amendment by which the majority of a 13-member Council are to be elected by members from the judiciary.

With the aim of discussing further constitutional adaptations that may occur before Kosovo's accession to the EU, this paper will examine the implications that the EU integration process will have on the current Constitution and potential amendments originating from this process. Comparative constitutional law provides a score of useful examples regarding constitutional alignment with the EU Treaties, particularly the cases of Slovenia and Croatia, which may serve as a useful roadmap for constitutional adaptations in Kosovo prior to accession to the EU.

\footnotetext{
2 The report is available at <http://ec.europa.eu/enlargement/pdf/key_documents/2015/20151110_report_kosovo.pdf> accessed 21 November 2016.

3 Siniša Rodin, 'Pridruživanje Hrvatske Europskoj uniji: preobrazba pravnog sustava' in Katarina Ott (ed). Pridruživanje Hrvatske Europskoj uniji: Izazovi ekonomske i pravne prilagodbe (Institute of Public Finance and Friedrich Ebert Stiftung 2003). See also Michael Baun and Dan Marek, The New Member States and the European Union: Foreign Policy and Europeanization (Routledge 2013).

4 The 2015 EU progress report for Kosovo (n 2).
} 
Initially, a brief overview is provided of the Kosovo Constitution and its amendments, followed by an elaboration of the status of international law in the Kosovo Constitution. As will be discussed below, the Kosovo Constitution is among the newest in the world, and was drafted under robust international supervision in order to accommodate the requirements originating from Martti Ahtisaari's Comprehensive Proposal for the Kosovo Status Settlement (hereinafter: the Ahtisaari Plan). ${ }^{5}$ With regard to EU integration, the paper will discuss the constitutional basis for Kosovo's accession to the EU and will examine several specific constitutional issues which may require modification during the EU pre-accession process, such as the right to vote, the freedom of movement and the extradition of nationals. While constitutional changes other than those discussed below can yet emerge during negotiations with the EU, this article only attempts to shed light on specific constitutional adaptations required during Kosovo's pre-accession process by providing concrete proposals for constitutional change to ensure compliance with the EU treaties. Besides this, the constitutional adaptations that have occurred in Central and Southeast European countries will be considered. These can be useful for Kosovo when addressing constitutional issues in the course of the EU pre-accession process.

\section{The Kosovo Constitution: a brief overview}

In 2008, Kosovo adopted its Constitution which, by and large, was designed within the parameters set forth in the Ahtisaari Plan. ${ }^{6}$ The Constitution follows the patterns of a modern constitution in terms of the institutional structures premised upon the separation of powers but also in the context of individual constitutional guarantees through a catalogue of constitutional rights and freedoms entrenched in Chapter 2. Given that the constitutional drafting process was internationally supervised, the preamble of the Constitution is not rooted in the country's historical foundations, but it merely states Kosovo's aspirations for Euro-Atlantic values and European integration. ${ }^{7}$ The Constitution also contains a set of constitutional values that are supposed to guide understanding of the Constitution and devotes a special chapter promoting the rights and freedoms of the non-majority communities. These are specific rights that are provided in addition to those guaranteed in the Constitution's

\footnotetext{
5 Martti Ahtisaari was a United Nations Special Envoy to Kosovo.

6 Joseph Marko, 'New Kosovo Constitution in a Regional Comparative Perspective' (2008) 33 Review of Central and East European Law 437; Dren Doli and Fisnik Korenica, 'Calling Kosovo's Constitution: A Legal Review’ (2010) 22 Denning Law Journal 51; John Tunheim, 'Rule of Law and the Kosovo Constitution' (2009) 18 Minnesota Journal for International Law 371.

7 Marko (n 6) 437.
} 
catalogue of human rights. ${ }^{8}$ These rights of the communities contain extensive constitutional guarantees to enable adequate representation of non-majority communities in Kosovo in almost every aspect of public life. ${ }^{9}$ For example, members of non-majority communities are guaranteed reserved seats or membership in the Assembly of Kosovo but also in the Government and judiciary, including two judgeship positions at the Constitutional Court. ${ }^{10}$ The Constitution has established a parliamentary republic whereby the government led by a prime minister is collectively responsible before the Parliament. ${ }^{11}$ The head of state is elected by the Assembly and is responsible to ensure the constitutional functioning of state institutions. ${ }^{12}$ The head of state has limited competences in the area of legislation (the President enjoys the constitutional right to veto laws passed by the Assembly) and in the justice sector since it has the power to appoint judges and prosecutors upon proposals of the Kosovo Judicial or Prosecutorial Council. ${ }^{13}$ Finally, it is worth mentioning that the Kosovo Constitution is quite rigid given the procedures that are required for its amendment. Draft constitutional amendments require initially an a priori review by the Kosovo Constitutional Court (KCC), and a two-thirds qualified parliamentary majority, including two thirds (2/3) of all deputies of the Assembly holding reserved or guaranteed seats for representatives of non-majority communities in Kosovo. ${ }^{14}$ Since the entry into force of the Constitution in June 2008, a total of 25 constitutional amendments have been adopted. There are two main factors that have contributed to this high number of constitutional amendments in a little less than a decade since the enactment of the Constitution. First, the 22 constitutional amendments enacted in September 2012 came as a result of the termination of Kosovo's international supervised independence. ${ }^{15}$ The result was that the International Civilian Office (ICO), which was established after Kosovo's declaration of independence, terminated its mandate, a decision which paved the way for the full enjoyment of the powers of state insti-

\footnotetext{
8 Kosovo Constitution, art 57.

9 Emma Lantschner, 'Protection of Minority Communities in Kosovo: Legally Ahead of European Standards -Practically Still a Long Way to Go' (2008) 33 Review of Central and East European Law 451-490.

10 See the Kosovo Constitution, arts 62, 65, 96, 108 and 114.

11 Kosovo Constitution, art 97(1).

12 ibid, art 84.

13 ibid, art 84.

14 ibid, art 144.

15 As already mentioned, the first 22 amendments were adopted in 2012 related to the ending of the international supervision of the independence of Kosovo. Amendment no 23 gave the Kosovo Assembly the power to grant amnesty while constitutional amendment no 24 adopted in 2015 provided for the establishment of the Specialist Chambers and the Specialist Prosecutor's Office. For more details, see the Official Gazette in Kosovo <http:// gzk.rks-gov.net/ActsByCategoryInst.aspx?Index=1\&InstID=1\&CatID=1> accessed 18 November 2016.
} 
tutions. The other factor that triggered constitutional changes in Kosovo in 2015 was the international community's call for the establishment of specialised courts to try crimes allegedly committed in 1999-2000. In response to this call, the Assembly passed constitutional amendments and Law No 05/L-053 to enable the establishment of the Specialist Chambers and the Specialist Prosecutor's Office. ${ }^{16}$ The Specialist Chambers will have jurisdiction for crimes within their subject matter jurisdiction which occurred between 1 January 1998 and 31 December 2000 and will have primacy over all other courts in Kosovo. ${ }^{17}$ In 2016, the Assembly passed Constitutional Amendment no 25 to ensure that the majority of Kosovo Judicial Council members are elected by their peers in line with the Venice Commission recommendations. ${ }^{18}$

\section{EU law supremacy}

One of the key principles of EU law is the principle of supremacy. Article I- 6 of the abandoned Constitutional Treaty provided that 'the Constitution and law adopted by the institutions of the Union in exercising competences conferred on it shall have primacy over the law of the Member States'. While some of the articles of the Lisbon Treaty imply the principle of EU law supremacy, such as article 4(34) TEU (which requires Member States to comply and not to hinder the objectives of the Union) or article 288 TFEU (on the direct applicability of the Regulations), nowhere does the Lisbon Treaty mention that EU law enjoys supremacy over national legislation. As Foster argues, the Lisbon Treaty 'sidestepped the direct expression of supremacy that was contained in Article I-6 CT by adding a Declaration (No 17) that instead supports supremacy by reference to the case law of the CoJ on supremacy'. ${ }^{19}$ Indeed the European Court of Justice (ECJ) has given special consideration to the principle of supremacy until it becomes accepted by the legal systems of the EU Member States. ${ }^{20}$ In other words, it was the ECJ which took the lead in providing basic constitutional principles on which the new legal order was based'. ${ }^{21}$

There are two important issues that deserve further elaboration regarding the supremacy of EU law. The first is related to the relationship

\footnotetext{
16 The law is available in the Official Gazette of Kosovo at <http://gzk.rks-gov.net> accessed 21 November 2016.

17 Law No 05/L-053 on Specialist Chambers and the Specialist Prosecutor's Office, arts 6-10.

18 The 2015 EU progress report for Kosovo (n 2).

19 Nigel Foster, EU Law Directions (OUP 2016) 136.

20 Evelyn Ellis and Philippa Watson, EU Anti-Discrimination Law (OUP 2012) 45. See also Case 26/62 Van Gend \& Loos [1963] ECR 1, 12 (English special edition).

21 Foster (n 19) 137.
} 
between national constitutions and EU law. There are several examples of how EU Member States have approached the question of the relationship between their constitutions and EU law depending on the constitutional tradition and the specifics of the national legal systems. In some states, like France and the Czech Republic, the relations between the Constitution and EU law are to be found in the context of the ratification of international agreements. For example, article 55 of the French Constitution accords supremacy to a ratified international treaty over national law. The same approach is followed by the Constitution of the Czech Republic, which in its article 10 states that every international treaty ratified by the Parliament of the Czech Republic is part of the Czech legislative order and takes precedence over all other laws. ${ }^{22}$ Some other countries, such as Greece and Ireland, were forced to make constitutional changes to reconcile the primacy of their constitutions with the supremacy of Union law. ${ }^{23}$ These constitutions have opted for the express mentioning of the supremacy of international law over national law. Article 28 of the Greek Constitution provides for the direct supremacy of international conventions, including EU treaties, over national legislation. ${ }^{24}$ But as EU law developments have unfolded, harmonisation of the supremacy of Union law with the primacy of national constitutions has generated so-called constitutional tolerance among members of the European Union. Such constitutional tolerance, as academic commentators argue, is premised on the concept that 'while the authority and reach of EU law is ultimately for national constitutional courts to decide, these courts commit themselves to recognize the special status of EU law'. ${ }^{25}$ This approach for the relative supremacy of EU law has been strongly echoed by a number of national constitutional courts along the lines of constitutional identity and fundamental rights guaranteed by national constitutions. ${ }^{26}$ Such conflicts between national and EU law have arisen in Germany, France and Italy, where constitutional courts have determined the limits of the acceptance of EU supremacy within the national constitutional order. ${ }^{27}$

\footnotetext{
22 Paul Craig and Gráinne De Búrca, EU Law: Text, Cases, and Materials (OUP 2015) 308.

23 Damian Chalmers, Gareth Davies and Giorgio Monti, European Union Law: Cases and Materials (CUP 2010) 190.

24 Under art 28 of the Greek Constitution '1) The generally recognized rules of international law and the international conventions after their ratification by law and their having been put into effect in accordance with their respective terms, shall constitute an integral part of Greek law and override any law provision to the contrary. The application of the rules of international law and international conventions in the case of aliens shall always be effected on condition of reciprocity'.

25 Chalmers (n 23) 194.

26 See, for example, the case decided by the German Constitutional Court, Solange I (1974)

2 CMLR 540, 550-1. The court's view in this case was that as long as EU law is able to secure the fundamental rights and freedoms guaranteed by the German Constitution, the principle of the supremacy of EU can be applied.

27 Craig and de Búrca (n 22) 278.
} 
The Polish Constitutional Court has also introduced 'firm limits on the acceptance of EU law' by arguing that the 'Constitution shall be the supreme law in Poland and the Polish courts have made clear that EU law does not take precedence over the Constitution'. ${ }^{28}$ The Constitutional Court argued that 'the precedence over statutes of the application of international agreements which were ratified on the basis of a statutory authorization or consent granted... in no way signifies an analogous precedence of these agreements over the Constitution'. ${ }^{29}$

The second issue concerns the relationship between EU law and domestic laws and this is clearly less problematic compared to the previous issue because the ECJ has from early on taken a position that national parliaments cannot unilaterally introduce laws that would be in conflict with EU law. As argued in Costa $v$ Enel, "by contrast with ordinary international treaties, the EEC Treaty has created its own legal system which, on the entry into force of the treaty, became an integral part of the legal systems of the member states and which their courts are bound to apply'. ${ }^{30}$ According to the ECJ, 'the transfer by the states from their domestic legal system to the community legal system of the rights and obligations arising under the treaty carries with it a permanent limitation of their sovereign rights, against which a subsequent unilateral act incompatible with the concept of the community cannot prevail'. ${ }^{31}$

As stated in the introduction, since Kosovo is not a member of the European Union, the issue of EU law primacy may not be relevant at the current phase of Kosovo's relationship with the EU. However, one of the first issues to be considered when Kosovo is ready to join the EU is whether EU law supremacy is implied in the Kosovo Constitution and whether such supremacy can be ensured without amending the Constitution. It should be noted that the Constitution does not address the relationship with EU law. While the supremacy of the Constitution is provided in article 16, nowhere does the Kosovo Constitution provide for the precedence of EU law over the provisions of national law.

But while the express supremacy of EU law is missing, the Kosovo Constitution provides for the precedence of international agreements and legally binding norms of international law over national laws. Whether the primacy of EU law can be sufficiently ensured on this basis is questionable given the unique nature of EU law as a supra-national law. One argument in support of this view is that the primacy of EU law over provisions of national law in Kosovo derives from the binding force of the

28 ibid 305.

29 ibid 305.

30 Case 6/65 Flaminio Costa $v$ ENEL, Reference for a preliminary ruling: Giudice conciliatore di Milano - Italy, judgment of 15 July 1964.

31 ibid. 
constitutional principle on the prevailing effect of ratified international agreements over the national legislation. Article 19(2) of the Constitution provides for the primacy of ratified international agreements and legally binding norms of international law over Kosovo laws. One can argue that ratification of the EU Treaties in conformity with the Constitution would sufficiently ensure the supremacy of EU law over the national legislation and that no constitutional amendments would be required in the Kosovo Constitution to ensure the supremacy of EU law. ${ }^{32}$ However, as the experience of Member States has shown, the explicit entrenchment of the precedence of EU law at the level of the Constitution is important to ensure the consistent application of EU law at the national level. One such example is the Croatian Constitution, which states that legal acts and decisions accepted by the Republic of Croatia in the institutions of the European Union shall apply in the Republic of Croatia in accordance with the acquis communautaire'. ${ }^{33}$ Although the Croatian Constitution does not provide explicitly for the primacy of EU law, it does so implicitly given the fact that the acquis is by its very nature to be applied in line with the principles of direct and interpretative effect and primacy over national law, which have been developed by the case law of the Court of Justice'. ${ }^{34}$ This is what Judge Rodin has called the constitutional affirmation of the fundamental principles on which EU law is founded, which also includes the supremacy of EU law and its direct effect on the national legislation. ${ }^{35}$ The Slovak Constitution has also provided that legally binding acts of the European Communities and European Union shall take precedence over the laws of the Slovak Republic. ${ }^{36}$ The supremacy clause is also included

\footnotetext{
32 The ratification of the treaties establishing membership of other international organisations by virtue of art 18 of the Constitution requires a two-thirds vote of all deputies of the Kosovo Assembly. The Kosovo Constitution is silent regarding the hierarchy of legal acts. Nowhere in the Kosovo Constitution is there any formal statement of the sources of law and of the relationship between them, with the exception of art 16 of the Constitution, which provides in clear terms that the Constitution constitutes the highest legal act and other laws and other legal acts shall be in conformity with it. On the relationship between international law and national law in the case of Kosovo, see Visar Morina, Fisnik Korenica and Dren Doli, "The Relationship between International Law and National Law in the Case of Kosovo: A Constitutional Perspective' (2011) International Journal of Constitutional Law 274; Kushtrim Istrefi and Visar Morina, 'Judicial Application of International Law in Kosovo' in Siniša Rodin and Tamara Perišin (eds), Judicial Application of International Law in Southeast Europe (Springer 2015).

33 Art 145 of the Croatian Constitution. See more in Rodin and Perišin (n 32).

34 Rodin and Perišin (n 32) 148.

35 ibid 148.

36 Article 7(2) of the Slovak Constitution reads: '[1]egally binding acts of the European Communities and European Union shall take precedence over the laws of the Slovak Republic'. See Anneli Albi, EU Enlargement and the Constitutions of Central and Eastern Europe (CUP 2005); Anneli Albi and Peter Van Elsuwege. 'The EU Constitution, National Constitutions and Sovereignty: An Assessment of a "European Constitutional Order" (2004) 6 EL Rev 741-765; Anneli Albi and Jacques Ziller (eds), The European Constitution and National Constitutions: Ratification and Beyond (Kluwer Law International 2007).
} 
in the Slovenian Constitution pursuant to which legal acts and decisions of supranational organisations to which Slovenia is a party are applicable in Slovenia in compliance with the legal requirements of the organisations. ${ }^{37}$ In view of the above-mentioned constitutional adaptations, the most suitable option to accommodate the supremacy of EU law is by introducing a constitutional amendment, which would state the prevalence of EU law over the national law, similar to the way this is done in the Croatian and Slovak constitutions. In other words, for the purposes of ensuring the consistent application of EU law it appears to be necessary to adopt a constitutional amendment, which would deal separately with the supremacy of EU law over the laws of Kosovo. Such a constitutional entrenchment of EU law supremacy would avoid any constitutional ambiguity about whether or not the precedence of EU law is implied in the text of the Constitution and would ensure better compliance with EU norms and enhance its implementation through judicial and administrative agencies.

\section{Transfer of sovereignty to the EU}

To begin this analysis, accession to the EU affects the sovereignty of a state since it implies a certain encroachment on the state sovereignty of the acceding state. For this reason, the manner in which state sovereignty is defined in a constitution is an important aspect for the EU accession process. Almost all post-communist states in Europe re-formulated their 'sovereignty clause' in national constitutions to be able to gain membership of the EU. As constitutional law scholars argue, the post-communist countries had to open up towards international law to be able to join the European Union and engaged in 'a major process of constitutional revision to enable the transfer of a part of their sovereignty to a highly integrated supranational organization'. ${ }^{38}$

The Kosovo Constitution, having been drafted under strong international supervision, gave special consideration to the way 'state sovereignty' is defined. The aim was to ensure that 'state sovereignty' was defined in a manner that permits the conferral of sovereign powers to international organisations. This approach of the Constitution is consistent with the objectives of the Constitution's preamble, which makes an appeal for the European integration process. ${ }^{39}$ There are two constitutional avenues

\footnotetext{
37 George Bermann and Katharina Pistor (eds), Law and Governance in an Enlarged European Union (Bloomsbury Publishing 2004).

38 Albi (n 36) 1. See also Ersin Erkan and Antonija Petricusic. 'Constitutional Challenges Ahead the EU Accession: Analysis of the Croatian and Turkish Constitutional Provisions that Require Harmonization with the Acquis Communautaire' (2010) 6 Review of International Law and Policy.

39 Marko (n 6) 437.
} 
that should be considered to assess whether the Constitution enables a partial conferral of powers to supra-national organisations. Article 2 of the Constitution defines the concept of 'state sovereignty' in absolute terms by stating that ' $[\mathrm{t}]$ he sovereignty and territorial integrity of the Republic of Kosovo is intact, inalienable, indivisible and protected by all means provided in this Constitution and the law'.

One can plausibly argue that the above-mentioned formulation is an affirmation of Kosovo's political will to become an independent state. Others argue that the content of article 2 of the Kosovo Constitution should be seen in light of the 'historical and political context since such provisions frequently have the character of a response to political and legal problems of the past', recalling the example of the German Basic Law of 1949 and that of the US Constitution of $1787 . .^{40}$ But no matter what the reasoning behind the purpose of article 2, the Constitution has provided the possibility for a transfer of sovereignty to international organisations for specific matters in article 20, which states:

The Republic of Kosovo may on the basis of ratified international agreements delegate state powers for specific matters to international organizations.

2. If a membership agreement ratified by the Republic of Kosovo for its participation in an international organization explicitly contemplates the direct applicability of the norms of that organization, then the law ratifying the international agreement must be adopted by two thirds (2/3) vote of all deputies of the Assembly, and those norms have superiority over the laws of the Republic of Kosovo.

The wording of article 20 of the Kosovo Constitution is similar to article 90 of Poland's Constitution, which permits Poland through ratified international agreements to 'delegate to an international organization or international institution the competence of organs of State authority in relation to certain matters' ${ }^{41}$ The Kosovo Constitution does not specify the 'specific matters' based on which a conferral of sovereignty to an international organisation can be made. But it is assumed that they would include membership in international organisations, human rights or participation in international mechanisms for collective security. The reference in the Constitution that the transfer of sovereignty can be made only for 'specific issues' is important because it is echoed in the judgment

\footnotetext{
40 ibid 437.

41 An English version of the Constitution of the Republic of Poland is available at <www. sejm.gov.pl/prawo/konst/angielski/kon1.htm> accessed 15 November 2016. For more, see Foster (n 19) 211.
} 
of the German Constitutional Court (GCC) in the Lisbon Treaty case: "the obligation under European law to respect the constituent power of the Member States as the masters of the Treaties corresponds to the nontransferable identity of the constitution (Article 79.3 of the Basic Law), which is not open to integration in this respect'. ${ }^{42}$ The Kosovo Constitution does not contain such constitutional provisions that are not open to integration, nor has the KCC developed any case law to frame what Kosovo's constitutional identity is. However, as the GCC has warned if legislative or administrative competences are only transferred in an unspecified manner or with a view to further dynamic development, they risk transgressing the predetermined integration programme and acting beyond the powers granted to them'. ${ }^{43}$ Therefore, the Constitution's requirement that state sovereignty cannot be transferred in an unspecified manner is generally in line with this GCC decision. With regard to the content of article 20, the following observations can be made. First, despite the fact that the Constitution does not make any explicit reference to transferring state sovereignty to the EU specifically, a broader interpretation appears to suggest that the transfer of power to an international organisation is also meant to include 'a supra-national organisation', although many academic commentators argue that the EU is not an international organisation in the usual sense. ${ }^{44}$ Second, the Constitution does not require a mandatory referendum to authorise accession to the EU, but only requires parliamentary approval in the form of a qualified majority by reaching a two-thirds vote of the 120-member Assembly to ratify the agreement. This majority requirement to authorise the delegation of sovereignty to an international organisation is also provided in other constitutions, such as those of Latvia, Slovenia, Croatia, Hungary and Greece. ${ }^{45}$ Finally there seems not to exist any inviolable core content of the constitutional identity in the Kosovo Constitution to generate any constitutionally important tension between State willingness for integration and the principle of conferral. Therefore, unless otherwise required by the EU during the pre-accession process, it appears that no constitutional changes will be needed in the Constitution to enable a partial transfer of sovereignty to the EU.

\footnotetext{
42 The judgment of 30 June 2009 of the Federal Constitutional Court of Germany on the Lisbon Treaty, available at <www.bundesverfassungsgericht.de/SharedDocs/Entscheidungen/EN/2009/06/es20090630_2bve000208en.html> accessed 21 November 2016.

43 ibid.

${ }^{44}$ Helle Tegner Anker, Birgitte Egelund Olsen and Anita Rønne. 'Legal Systems and Wind Energy: A Comparative Perspective' (Kluwer Law International 2009) 46; See also Robert Schütze 'European Union Law' (CUP 2012).

45 Constitution of Hungary (art 2A); Slovenia (art 3a), Latvia (art 68 para.3).
} 


\section{EU specific issues}

In the following section I will analyse some specific issues in the Kosovo Constitution, whose content may require adaptation due to the European integration process. These specific issues include the right to vote and stand as a candidate at municipal elections, the extradition of nationals and the freedom of movement, currency and the powers of the Kosovo Central Bank. The EU has adopted a catalogue of citizens' rights and it is important to assess whether such segments of the Kosovo Constitution are in alignment with EU norms on citizenship rights and freedoms.

\section{1 The right to vote and to stand as a candidate at municipal elections}

Under article 20(2) of the Treaty on the Functioning of the European Union (TFEU), every citizen of the Union residing in a Member State of which he is not a national shall have the right to vote and to stand as a candidate at municipal elections in the Member State where he resides, under the same conditions as nationals of that State. ${ }^{46}$ Council Directive 94/80/EC has laid down detailed arrangements for the exercise of the right to vote and to stand as a candidate in municipal elections by citizens of the Union residing in a Member State of which they are not nationals. ${ }^{47}$ In fact, active and passive voting rights for EU citizens (former article 19 TEU) had previously been introduced in the Maastricht Treaty. The introduction of the right to vote and to stand as a candidate in municipal elections by citizens of the Union residing in a Member State of which they are not nationals has led to constitutional changes both in the constitutions of EU Member States and in those of the acceding states to ensure compliance with the former article 19(1) EC (now article 20(2) TFEU). ${ }^{48}$ As Anneli Albi argues, 'the reasons for such amendments lie in the traditional constitutional view that voting rights belong to citizens due to their inextricable bond with a nation-state, and many constitutions express this principle in some form'. ${ }^{49}$ In France, the Constitutional Council initially declared that EU citizens' electoral rights in local elec-

\footnotetext{
${ }^{46}$ Article 22 of the TFEU available at <http://eur-lex.europa.eu/legal-content/EN/ TXT/?uri=celex\%3A12012E\%2FTXT > accessed 18 November 2016.

47 Council Directive 94/80/EC of 19 December 1994 laying down detailed arrangements for the exercise of the right to vote and to stand as a candidate in municipal elections by citizens of the Union residing in a Member State of which they are not nationals [1994] OJ L368/38 http://eur-lex.europa.eu/legal-content/EN/TXT/?uri=celex:31994L0080 accessed 18 November 2016.

48 For more on the voting rights at the EU level, see Jean-Claude Piris. The Lisbon Treaty: A Legal and Political Analysis (CUP 2010). See also Federico Fabbrini, Fundamental Rights in Europe (OUP 2014).

49 Albi (n 36) 14.
} 
tions go against the 1958 French Constitution on the grounds that the holder of sovereignty in France is the people, therefore only French nationals form the electorate and are entitled to exercise the right to vote. ${ }^{50}$ The findings of the French Constitutional Council led to the adoption of constitutional amendments to enable ratification of the Treaty by incorporating a new article in the French Constitution that gave the right to vote and stand as a candidate in municipal elections to citizens of the Union residing in France. ${ }^{51}$ Further constitutional changes on voting rights were also made in Germany (article 28(1)), Portugal (article 15(5)), Austria (articles 23a and 117(2)), Spain (article 13(2)), Belgium (article 8(3)), and Croatia (article 146).

Given the above-mentioned constitutional revisions triggered by the EU integration process, we now turn to the Kosovo Constitution to examine whether a constitutional norm providing for the right to vote is compatible with article 20(2) TFEU. The Kosovo Constitution in its article 45 provides that 'every citizen of the Republic of Kosovo who has reached the age of eighteen, even if on the day of elections, has the right to elect and be elected, unless this right is limited by a court decision'. The content of the norm implies that 'nationality' is one of the key requirements for the exercise of the right to vote in Kosovo. Such a requirement should be seen merely in the historical context of the enactment of the Kosovo Constitution, but it also shows that not much consideration has been paid to the fact that local elections are not necessarily a manifestation of national sovereignty. A plain reading of article 45 of the Kosovo Constitution clearly implies that it would be impermissible for citizens of EU Member States to vote in local elections because the right to vote belongs only to Kosovo citizens. ${ }^{52}$ This being so, article 45 of the Constitution stands in contradiction to article 20(2) TFEU and may have to be reworded unless the KCC avoids such a normative collision by holding a view similar to that of the Polish Constitutional Tribunal (PCT), which ruled that 'granting foreign EU citizens the right to vote and to stand as a candidate at local elections does not contradict Article 62(1) of the Constitution, which guarantees Polish citizens the right to elect, inter alia, their representatives to organs of local self-government'. ${ }^{53}$ On this specific matter, the PCT did not find any contradiction between the Treaty and the Polish Constitution and argued that the "constitutional right is not of

\footnotetext{
50 Mark Tushnet and Thomas Fleiner, Routledge Handbook of Constitutional Law (Routledge 2013) 356.

51 Art 88 of the French Constitution.

52 See more in Rainer Bauböck, 'Expansive Citizenship - Voting Beyond Territory and Membership' (2005) Political Science and Politics 683.

53 Anna Wyrozumska (ed), Introduction to Polish Law (Lodz University Press 2005) 26. See also Adam Lazowski, Adaptation of the Polish Legal System to European Union Law: Selected Aspects (University of Sussex 2001).
} 
an exclusive character, in the sense that, should the Constitution grant it directly to Polish citizens, it might not also be vested in the citizens of other States'. ${ }^{54}$ It is interesting to note that it is precisely this issue that sparked intense debate in Poland as to whether EU citizens can participate in local elections in Poland merely on the basis of the Electoral Law and without amending the Constitution.

While this issue can be further discussed during screening and negotiations with the EU during the pre-accession process, there are different models of constitutional adaptations that can be followed to ensure compliance with the requirements of the Treaty on voting rights. One such example is the Croatian Constitution, which introduced constitutional affirmation of EU citizens' rights by providing that 'all rights guaranteed by the European Union acquis communautaire shall be enjoyed by all citizens of the European Union'. ${ }^{55}$ Other examples vary, from those constitutions which for elections for local self-government provide direct entitlement to non-nationals who have settled in a State for a longer period of time determined by a separate law (for example, the Hungarian Constitution) to where the right to elect and be elected to local public administration bodies is guaranteed for EU citizens who comply with the requirements of organic law (the Romanian Constitution). ${ }^{56}$ While these examples can serve as guidance to legislative authority in Kosovo, there is, of course, some degree of flexibility on the part of the acceding state regarding constitutional arrangements that can be made to ensure that EU citizens' right to vote and to stand as a candidate at local elections is duly ensured.

\subsection{Extradition of nationals}

The Framework Decision of 13 June 2002 on the European Arrest Warrant and other surrender procedures between Member States (Framework Decision) was enacted to abolish in the framework of the European Union the formal extradition procedure in respect of persons who are fleeing justice after having been finally sentenced and to speed up the extradition procedures in respect of persons suspected of having committed a criminal offence. ${ }^{57}$ The Framework Decision led to abolishing classi-

\footnotetext{
54 Judgment of 11 May 2005 - Ref. No. K 18/04. The judgment is available at <http:// trybunal.gov.pl/uploads/media/SiM_LI_EN_calosc.pdf> accessed 21 November 2016.

55 Constitution of Croatia, art 146.

56 Constitution of Romania, art 16. The text of the Constitution is available at <http:// www.cdep.ro/pls/dic/site.page?den=act2_2\&par1=2\#t2c2s0sba36> accessed 21 November 2016.

57 Council Framework decision No 2002/584/JHA of 13 June 2002 on the European Arrest Warrant and other surrender procedures between Member States [2002] OJ L190, 1. For more on constitutional aspects of the European Arrest Warrant, see Oreste Pollicino, 'European Arrest Warrant and Constitutional Principles of the Member States: A Case LawBased Outline in the Attempt to Strike the Right Balance between Interacting Legal Systems' (2008) 9(10) German Law Journal 1313; Daniel Sarmiento, 'European Union: The
} 
cal extradition between individual Member States and replacing it with a system of surrender between individual judicial authorities. Accordingly, persons suspected of having committed a criminal offence will no longer be turned over on the basis of an individual act of the executing state, but directly on the basis of a court decision in the requesting EU Member State, which thus has direct effect in the executing state. The activities of central authorities are replaced by cooperation between individual courts, and the role of the central authorities is thus limited to practical and administrative assistance. From a national constitutional law perspective, the outcome was that the implementation of the Framework Decision encountered serious constitutional challenges in the Member States given that national constitutions protected their citizens from extradition. To put it differently, the enactment of the EAW has, in turn, led to constitutional revisions in countries such as Slovenia, Bulgaria, Romania and Croatia. ${ }^{58}$ In Croatia, the constitution did not allow extradition of its citizens to another state, and in order to enable the implementation of the Directive it was necessary to amend the Constitution to permit Croatian citizens to be forcibly extradited to another State in the case of the execution of a decision on extradition in compliance with an international treaty or the acquis communautaire of the European Union. ${ }^{59}$ In some Member States, the implementation of the EAW was contested on constitutional grounds before constitutional courts, as in Poland and the Czech Republic. Having been confronted with this issue, the Polish Constitutional Court ruled that the surrender of its citizens to a Member State is incompatible with constitutional rights and freedoms. ${ }^{60}$ The Czech Constitutional Court, on the other hand, succeeded to 'reconcile the constitutional prohibition of forcing a person to leave his or

European Arrest Warrant and the Quest for Constitutional Coherence (2008) 6(1) International Journal of Constitutional Law 171; Adam Lazowski, 'Poland: Constitutional Tribunal on the Surrender of Polish Citizens under the European Arrest Warrant. Decision of 27 April 2005' (2005) 1(3) European Constitutional Law Review 569.

58 Art 47 of the Slovene Constitution; art 25(3) of the Bulgarian Constitution; art 19(1) of the Romanian Constitution.

59 Art 9 of the Croatian Constitution provides that 'a citizen of the Republic of Croatia may not be forcibly exiled from the Republic of Croatia nor deprived of citizenship, nor extradited to another state, except in case of execution of a decision on extradition or surrender made in compliance with an international treaty or the acquis communautaire of the European Union'. For more, see Anthony Moore and Mario Chiavario, Police and Judicial Co-operation in the European Union: FIDE 2004 National Reports (CUP 2004) 37. See also Zdeněk Kühn, 'The European Arrest Warrant, Third Pillar Law and National Constitutional Resistance/Acceptance: The EAW Saga as Narrated by the Constitutional Judiciary in Poland, Germany, and the Czech Republic' (2007) 3 Croatian Yearbook of European Law and Policy 99.

60 Polish Constitutional Tribunal, Judgment of 27 April 2005, Case P 1/05. English translation available at < http://trybunal.gov.pl/fileadmin/content/omowienia/P_1_05_full_ GB.pdf> accessed 21 November 2016 . See also House of Lords, European Union Committee. 'European Arrest Warrant - Recent Developments' (HL 2005-06, 156). The document is available at <www.publications.parliament.uk/pa/1d200506/1dselect/ldeucom/156/156. pdf> accessed 22 November 2016. 
her homeland with the EU obligation of surrendering one's citizens to another member state' by concluding that the implementation of the EAW framework decision does not violate the Czech Constitution. ${ }^{61}$

We now turn to article 35(4) of the Kosovo Constitution to assess whether its content is compatible with the EAW framework. Article 35(4) provides that Kosovo citizens 'shall not be extradited from Kosovo against their will except for cases when otherwise required by international law and agreements'. ${ }^{62}$ There are two important aspects that should be considered as far as compliance with the EAW is concerned. First, as opposed to the above-mentioned constitutions, the Kosovo Constitution does not place a complete ban on the surrender of its citizens to other jurisdictions. And second, while it provides that the forcible extradition of its citizens is prohibited, extradition of citizens to foreign jurisdictions can be made effective if required by rules of international law or following an international agreement which Kosovo authorities have ratified. In addition, the Kosovo Constitution, as amended, goes even further by allowing any person accused of crimes before the Specialist Chambers to be detained on remand and transferred to specialist chambers sitting outside the territory of Kosovo. ${ }^{63}$ Therefore, in contrast to those countries in which the European Arrest Warrant has been found to be in conflict with the constitution, the extradition of Kosovo citizens to foreign jurisdictions does not seem to cause any constitutional issue in Kosovo. Thus, implementation of the Framework Decision should not require any constitutional amendment, except the requirement for transposing the EAW, when Kosovo joins the EU.

\subsection{Freedom of movement, currency and the powers of the Central Bank}

Another issue is related to freedom of movement, the currency and the power of the Central Bank in Kosovo in respect of whether they are compatible with the TFEU. It should be recalled that freedom of movement is one of the core rights, which derives from the EU citizenship concept. Article 21 TFEU guarantees citizens of the Union the right to move and reside freely within the territory of the Member States, while article 45 TFEU provides that 'freedom of movement for workers shall be

\footnotetext{
${ }^{61}$ Marise Cremona, Compliance and the Enforcement of EU Law (OUP 2012) 141. See the Czech Constitutional Court Judgment of 3 May 2006 (66/04).

62 The Law on International Legal Cooperation in Criminal Matters regulates further conditions and procedures regarding the international legal assistance in criminal matters, including extradition of Kosovo citizens to foreign national jurisdictions. The law is available at www.md-ks.net/repository/docs/Ligji_per_bashkepunim_Juridik_(anglisht).pdf accessed 22 November 2016.

63 See amendment no 24 of the Kosovo Constitution, art 162(8), which is available at <https://gzk.rks-gov.net/ActDetail.aspx?ActID=10997> accessed 22 November 2016.
} 
secured within the Union'. Freedom of movement is one of the key instruments for the EU and its Member States to ensure competition and movement of goods and services. In its decision in the D'Hoop case, the Court of Justice of the EU argued that:

In that a citizen of the Union must be granted in all Member States the same treatment in law as that accorded to nationals of those Member States who find themselves in the same situation, it would be incompatible with the right of freedom of movement were a citizen, in the Member State of which he is a national, to receive treatment less favourable than he would enjoy if he had not availed himself of the opportunities offered by the Treaty in relation to freedom of movement. ${ }^{64}$

To comply with the requirements of the TFEU, constitutions of the EU Member States guarantee the freedom of movement to everyone without limitations on nationality. For example, the Croatian Constitution states that 'anyone lawfully within the territory of the Republic of Croatia shall enjoy freedom of movement and freedom to choose his/her residence' while the Slovenian Constitution provides that 'everyone has the right to freedom of movement, to choose his place of residence, to leave the country and to return at any time'. ${ }^{65}$ The freedom of movement is also conferred on everyone according to article 52 of Poland's Constitution and article 23 of the Slovak Constitution.

From a broader perspective, freedom of movement remains one of the biggest challenges for Kosovo citizens since they remain the only citizens in the Western Balkans who are unable to travel without a visa to EU countries. Kosovo citizens can travel visa-free only to a few countries in the immediate neighbourhood, which makes Kosovo 'one of the most isolated places on earth'. ${ }^{66}$ While in May 2016 the European Commission proposed to the Council and the European Parliament the lifting of visa requirements for the people of Kosovo by transferring Kosovo to the visafree list for short-stays in the Schengen area, the proposal has not been approved yet by the European Parliament and the Council, and Kosovo citizens continue to be deprived of exercising one of the most fundamental rights of the TFEU. ${ }^{67}$ From the perspective of Kosovo's Constitution,

64 Case C-224/98 MN D'Hoop [2002] ECR I-6191.

65 Article 32 of the Croatian Constitution. See art 52 of the Slovenian Constitution.

66 European Stability Initiative, 'Isolating Kosovo? Kosovo vs Afghanistan 5:22' (ESI Discussion Paper (Online) 19 November 2009) 2. Available at <www.esiweb.org/pdf/esi_document_id_111.pdf> accessed 17 March 2016.

67 European Commission, 'European Commission Proposes Visa-free Travel for the People of Kosovo (Press Release, 4 May 2016) <http:/ / europa.eu/rapid/press-release_IP-16-1626_ en.htm> accessed 10 October 2016 . 
freedom of movement is one of the basic fundamental rights entrenched in Chapter 2. Article 35(1) of the Kosovo Constitution provides that every citizen of Kosovo or a foreigner who is a legal resident of Kosovo has the right to move freely throughout the territory of Kosovo and to choose his/her location of residence. As is seen, article 35(4) of the Constitution distinguishes between 'nationals' of Kosovo and 'foreigners' who are legally residing in Kosovo as far as the exercise of freedom of movement is concerned. While it is not entirely clear what a 'foreign legal resident' means in the context of article 35(4) of the Constitution, the Kosovo Law on Foreigners, which regulates the conditions of the entry, movement, residence and employment of foreigners in the territory of Kosovo, states that a 'foreigner' is any person who is not a citizen of Kosovo. ${ }^{68}$ Given the above-mentioned distinction and the legal uncertainty that may arise, article 35(4) of the Kosovo Constitution should be reformulated to ensure that freedom of movement is guaranteed to everyone without limitations on nationality. As noted above, the Treaty within the scope of its application prohibits any discrimination on the rights of movement (art 18 TFEU) on the grounds of nationality, and article 35 of the Kosovo Constitution should be brought into harmony with article 21 TFEU. One could argue that a maximalist interpretative approach can imply that the Kosovo Constitution may not require constitutional amendment with regard to freedom of movement since article 20 TFEU accords every person holding the nationality of a Member State the status of citizen of the Union. Therefore, the Treaty provisions on freedom of movement would apply in the Kosovo constitutional order as well when Kosovo joins the EU. As mentioned earlier, much will depend on whether such an interpretation will be considered adequate, and thus a formal constitutional amendment on freedom of movement would be avoided.

For readers it would also be interesting to briefly discuss whether the Kosovo Constitution contains provisions on the issuing of currency and the powers of the Central Bank since such provisions have caused problems in some Member States that joined in 2004. For example, before Estonia joined the EU in 2004, the Estonian Supreme Court was confronted with a constitutional question as to whether article 111 of the Estonian Constitution (which provided that only the Estonian Central Bank has the right to issue currency in Estonia) complies with EU law. The Estonian Supreme Court ruled that Estonia was 'entitled to join the euro-zone, as the Treaties take precedence over its constitution'. ${ }^{69}$ The Kosovo Constitution talks about currency and the Central Bank in general terms. Article 11 of the Constitution provides that Kosovo 'uses as

\footnotetext{
68 Law no 04/1-219 on foreigners, art 3. The law is available at <https://gzk.rks-gov.net/ ActDetail.aspx?ActID=8876> accessed 21 November 2016 .

69 Chalmers (n 23) 190.
} 
legal tender one single currency' but does not specify what that currency is, although Kosovo has used the Euro as an official currency since 2002. As far as the Central Banking Authority (CBA) is concerned, the Constitution only states that the CBA is an independent authority but does not state that the CBA has any exclusive power to issue national currency. Hence, unlike the case of Estonia, the Kosovo Constitution does not seem to require any constitutional adjustment regarding currency provisions and the CBA's competence to issue currency.

\section{Conclusion}

While it is undisputed that ratification of the Stabilisation and Association Agreement with the EU has advanced Kosovo in terms of the EU integration process, Kosovo is still far from EU accession. Therefore, a screening of its Constitution for compliance with EU law is not yet required, at least not formally. This article, however, has discussed prospective constitutional amendments which may arise when Kosovo is able to join the European Union. As we have noted, the Kosovo Constitution is one of the newest in Europe and its content generally permits the EU integration process, which is one of the major objectives of the Constitution's preamble. However, as the experience of other Member States has shown in the process of preparations for accession, there are several issues in the Kosovo Constitution that may require modification as the country approaches the process of European integration. Key among them are the 'partial transfer of sovereignty' and the 'precedence of EU law', to which the Kosovo Constitution indirectly refers. Still, as the article has shown, there remain some specific constitutional issues that should be considered in light of pre-accession adaptations, such as the right to vote and stand in local government elections, the freedom of movement and the extradition of nationals, which will require constitutional adjustment through constitutional amendments. Unquestionably, as noted above, additional constitutional changes other than those presented above can yet arise during negotiations with the EU to meet the requirements of integration into the EU legal system. Speaking of this, it might be possible that some EU integration issues affecting the Kosovo Constitution may be addressed within Chapter 23, which deals with the judiciary and fundamental rights. But, until then, the findings of this article can serve as a preliminary orientation regarding the Constitution's compliance with EU law and potential constitutional adjustments, which will derive from the EU pre-accession process. 